\title{
WEALTH AND POLITICAL INFLUENCE IN THE EXPANSION OF CHRISTIAN FRONTIERS IN CONTEMPORARY NIGERIA: THE CLAPHAM SECT LESSON
}

\author{
Kanayo Nwadialor \& Chinedu Emmanuel Nnatuanya \\ http://dx.doi.org/10.4314/og.v12i s1.9
}

\begin{abstract}
The business of the expansion of any religious frontier is highly demanding. It is a business that has both spiritual and physical components for its effectiveness in the society. Spiritually, it demands prayers while physically; material possessions like money and political influence become veritable tools in enhancing its effectiveness in the world. Historically, the declaration of the Christian faith as legal religion in the Roman Empire by Constantine in the fourth century played a major role in the expansion and the subsequent consolidation of the Church. Likewise, the Clapham sect of the $18^{\text {th }}$ and $19^{\text {th }}$ centuries played a significant role in the expansion of the Church beyond the shores of Europe. Their role shows that money and political influence are good vehicles for expanding the gospel of Christ in every part of the world. This work is aimed at a espousing the role of the Clapham sect in the expansion of Christianity in the $19^{\text {th }}$ century. The aim is to use it as a guide on the best way for Christians to use their wealth and influence towards the expansion of Christianity in contemporary Nigeria. Hence, the work will apply historical method in its evaluation and interpretation.
\end{abstract}

\section{Introduction}

It is now history that the $18^{\text {th }}$ century Europe witnesses a rise in the evangelization zeal of Christians in fulfilling the mandate of the great commission, - to take the gospel to the end of the world. This period is marked by the First Great Awakening which coincided with the expansion of the Spanish and Portuguese empires around the world. And this expansion greatly helped the spread of Roman Catholicism. On this, it is important to note that the First Great 
Awakening was a result of rise in the religious zeal among Protestants in 1730s and 1740s. This awakening result from powerful preaching that deeply affected hearers with a deep sense of conviction of the sinful nature of man and the need for repentance. The overall effect was the reform of traditional liturgies and ceremonies. Ahlstrom (1972) saw it as part of a "great international Protestant upheaval" that also created Pietism in Germany, the Evangelical Revival, and Methodism in England" (p. 263).

In the same vein, Clapham sect can be said to be a product of the First and Second Great Awakening. However, it was greatly influenced by the Second Great awakening of 1800 that emphasized reaching out to the "unchurched". This new spiritual wave caused people of different categories to be passionately and emotionally involved in their confessed faith, rather than being passive listeners to intellectual discourse in the name of religion. In view of this development, people began to study the scripture. This passion and desire gave birth to many evangelical groups that were convinced on the need to reach out to the unreached with the gospel message of Jesus Christ. This passion increased the tempo of Evangelicalrevivals which according to Bebbington (1993) has four distinctive features: conversionism, biblicism, crucicentrism, and activism.

Conversionism: This is the belief in the necessity of new birth also called "born again". It entails repentance from sin. In essence, it is conversion that differentiates the Christian from the non-Christian.

Biblicism: This is having a reverence for the scripture and a high regard for biblical authority.

Crucicentrism: This refers to the atonement through the saving death and resurrection of Jesus Christ, the Son of God that offers forgiveness of sins and new life to anyone that believes in him.

Activism: This describes the tendency towards active expression and sharing of the gospel in diverse ways that include preaching and social action. It is practical oriented mission. 
It was these convictions that gave birth to the Clapham sect so as to meet the needs of people who have no access to the gospel. Such convictions entail the use of their wealth and political influence to bring about the necessary changes that will promote the Great Commission. The historical methodapplied in the interpretation of this work is the tool that helps in the interpretation of past events in other for the present to learn from it so as to change the future for the betterment of humanity and the society at large.

\section{Clapham Sect in Historical Perspective}

To some, the Clapham sect was a group of social reformers or preachers whose emphasis was on the social responsibility of the gospel to the world. While for others, they were revivalist whose emphasis is centered on taking the gospel message to the unreached of the world. No matter how one sees them, this sect was very vital in the mission of the Church in the $19^{\text {th }}$ century. But, how did this sect come to be?

Historically, Clapham Sect was a gathering of group of people with the same passion and zeal for the cause of the gospel to meet the needs of the afflicted and dejected in the world. This meeting of convinced Christians in the Anglican Church of England started in a village called Clapham in London between 1790 to1830. According to Hardman (n.d), Clapham was at that time a peasant village that latter grew into a residential centre with some two thousand inhabitants. The village is three miles distant from London. One may ask, why Clapham? Clapham was the choice because most of the members of this new Evangelical resided there at that point in time. No wonder Stephens (2010) describes them as:

A network of friends and families in England, with William Wilberforce at its centre of gravity, who were powerfully bound together by their shared moral and spiritual values, by their religious mission and social activism, by their love for each other, and by marriage. (p.1).

On the other hand, McKenzie (2010) argues that this group was not a sect because it had no distinctively separate beliefs from the current of evangelical Christianity that had resulted from the 
eighteenth century Methodist revivals. Rather, it was a group that stirred the Puritan heritage of the established Church of England and challenged the formalism and corruption of eighteenth century Christianity. Newman (2010) in his own view observes that the sect was never more than 25 persons, but they were people of influence, many choosing to live close to each other in the village of Clapham, near London.

It is noteworthy to mention that some of its founding members include: Thomas Fowell Buxton (1786-1845), Member of Parliament (MP) and Brewer, William Dealtry (1775-1847), Rector of Clapham, Mathematician, Edward James Eliot (1758-97), Parliamentarian, Thomas Gisbourne (1758-1846), Cleric and author, Charles Grant (1746-1823), Administrator, Chairman of the Directors of the British East India Company, Katherine Hankey (1834-1911), Evangelist, Zachary Macaulay (1768-1838), Estate Manager, Colonial Governor, Hannah More (1745-1833), Writer and Philanthropist, Granville Sharp (1735-1813), Scholar and Administrator, Charles Simeon (1759-1836), Anglican Cleric, Promoter of missions, James Stephen (1758-1832), Master of Chancery, Lord Teignmouth (1751-1834), Governor-General of India, Henry Thornton (1760-1815), Economist, Banker, Philanthropist, MP for Southwark, Henry Venn (1725-97), Founder of the Clapham sect, John Venn (1759-1813), Rector of Holy Trinity Church, Clapham, William Wilberforce (1759-1833), MP, William Smith (1756-1835), MP.

Looking at the personalities involved, one may be wondering, what brought these great men together? In response to the above, it seems that the factors that drew these men together were their passion for evangelical Christianity and the joy of good fellowship with like-minded people who combined an enjoyment of life with a commitment to principle. In support of this, Richard (2001) states that perhaps, the sect will be remembered because they shared a common commitment to Jesus Christ and a clear sense of calling.They were committed to lifelong friendship and mutual submission was the norm. Their advocacy was marked by careful research, planning and strategy.They worshiped both privately and publicly, gathering twice weekly at the Clapham Church. Their friendships were inclusive and focused on the essentials. For example, Wilberforce was a Wesleyan and his closest friend, Henry 
Thornton, was a Calvinist.They made family life a clear priority and delighted in each other's marriages and children.They kept the long view on completing projects. For instance, abolition of the slave trade took 20 years. They made no dichotomy between evangelism and social action. They recognized each other's passions and supported one another in addressing them.

In the same vein, Coupland (cited in Richard, 2001) observes:

It was a remarkable fraternity - remarkable above all else, perhaps, in its closeness, and in its affinity. It not only lived for the most part in one little village; it had one character, one mind, one way of life. They were mostly rich, living in large roomy houses; but they all were generous givers to the poor. Thornton indeed gave away as much as sixsevenths of his income till he married, and after that at least a third of it. They could mostly have been of leisure but they all devoted their lives to public service. They were what Wilberforce meant by 'true Christians'. (p. 23).

In essence, the love of God was the very centre of the group's reason for being together.

\section{Clapham Sect: Its Impacts to Humanity, Christian Mission and the Society}

For one to appreciate the role of Clapham sect one must understand the condition of England and Europe at the beginning of the18th century. Describing this, Diane (n.d) observes that "England, at the beginning of the eighteenth century, was in a moral quagmire and a spiritual cesspool" (p.1). She went further to state that morally, the country was becoming increasingly decadent to the extent that drunkenness was rampant and gambling was so extensive. More so, newborns were exposed in the streets and ninety-seven percent of the infant poor died as children. What an ugly situation?

In addition, slave trade was common and rampant in such a way that human dignity was lost while the beneficiaries were not willing to disengage from such immoral business. In fact, one can 
conclude that during this period morality and religion in Britain had collapsed to a degree that was never known in any Christian country.

No wonder that Finn (n.d) maintains that Clapham Spirituality is a model for how contemporary evangelicals can thoughtfully and effectively combine the twin emphases of personal spiritual formation and faith-inspired social activism to promote the cause of the gospel. This sect is understandably most famous for its role in ending slavery, but it is important to understand that their anti-slavery motivations were grounded in their faith. For them, slavery was an abomination because every human being is created in God's image. In other words, the crusade against slavery was a moral crusade born out of Clapham Spirituality.

More so, their impact was so enormous because they were active participants to the extent that most of them were members of British Parliament. Such involvement helped them to work for prison reform, prevention of cruel sports, the suspension of the game laws and the lottery. In addition, they supported several missionary and Bible societies, financed Hannah Moore's schools and pamphlets, and published their own Journal, The Christian Observer. Also, the Clapham spirituality was not afraid to engage politically. According to Hylson-Smith (1988), "the Sect established the practice of politics as a true Christian vocation" (p. 93). In support of this,Bradley (1974) maintains that over 1000 Evangelicals were members of the Parliament in the period $1780-1830$. He also stated that they were not passive but active members who were heads of different committees because of their hard work and faithfulness to duty.Furthermore, it is noteworthy that they played a vital role in the establishment of new missionary societies especially the Church Missionary Society which offers support to different British colonies. In support of this, Tomkins (2010) describes the impact of Clapham Sect in this way:

What was at stake in the Clapham Sect's proposals for India was a vision for a new kind of empire. The British Empire in Africa was a matter of mere pillage, that in the Caribbean, slave-driving and the British North America had carried on, as far as possible, as if the native peoples did not exist; and British India was a secular trading concern. However, Clapham believed that British presence 
should improve the world, spiritually, materially, socially and politically. Also, that Britain had the truest religion, the most benign constitution and the most advanced society, and was duty bound to share it. Nevertheless, it does so in three respects which can all be called the legacy of the Clapham Sect: the missionary movement and the Church Missionary Society (CMS), the Aborigines Protection Society; and the dominant presence of the second generation in the Colonial Office. (p.2).

\section{Lessons for Nigerian Christians and Political Leaders}

The action and attitude of the Clapham sect is full of lessons for Christians of our contemporary times in that their life displayed the practical gospel as taught by Jesus Christ in his mission statement in Luke 4: 18 - 19:

The Spirit of the Lord is upon me, because he hath anointed me to preach the gospel to the poor; he hath sent me to heal the brokenhearted, to preach deliverance to the captives, and recovering of sight to the blind, to set at liberty them that are bruised, to preach the acceptable year of the Lord.

In other words, true Christianity in the mind of God is such that takes care of the poor, the oppressed, the rejected, the voiceless, the orphan, widows and the sick among others in the society. Hence, Christianity is all about practical oriented programes that will enhance the holistic well-being of the people. In view of this, it is paramount that the well to do Christians will see it as their responsibility to carry out the great commission in the nook and cranny of our society so as to address the unhealthy situations suppressing the poor and the down trodden. Collaborating with this fact, Nnatuanya (2011) maintains that "William Willberforce and his group saw themselves as trustee under God to use their favoured social position and wealth in ameliorating the ills of the society" (p.2). In this vein, it is important for Africans to understand leadership in the words of Drucker (1968) thus," 
Leadership is lifting of man's vision to higher sights, the raising of man's performance to a higher standard and building of a man's personality beyond its normal limitation"(p.195). In line with this fact, Drucker went further to state that effective leadership looks primarily on the strengths and not the limitations of the led and looks for ways of cementing together the strength of these people into a formidable force for meaningful development and progress. Therefore, what Africans need are leaders who can galvanize the human resources in Africa for the upsurge of her development.

Likewise, contemporary leaders in Africa need to have such understanding that their position and wealth are for service and not for personal acquisition. It is on this backdrop that the action of Dr Good luck Jonathan, former president of the federal republic of Nigeria, in the 2015 general election Nigeria is something to applaud. He navigated the oceans to subdue pride and the pleasure of power to accept defeat in an election even though they said election was not necessary free from rigging by the opposition. However, for the sake of peace and the good of the masses he played safe as God fearing leader who believes in the dignity of human life. This is seen clearly in his words:

I believe that character matters in leadership. And it is not just about who becomes the President of a country, but somebody has to be there and the person needs the support of all to succeed. I made a choice to keep the country away from conflict. I have always advised other African leaders that we will need to have a country before we can have the ambition to become President. We do not have to expose our people to deaths because we want to stay in power. Some people hold on to power, may be, for fear of the unknown ... My commitment is to always put the country before my personal ambition and that is what I have demonstrated.

Indeed, such action serves as a great lesson for other world leaders to follow. 
More so, as the Clapham sect was active in the political life of their time, it is necessary that Christians of nowadays must change their mindset about African politics if they must bring about meaningful and enduring change in Africa. For this is the only way Africa can move ahead in the midst of the numerous challenges facing her in the global community. In other words, for Africa to develop, the Evangelicals in Africa must rise up to the challenge of governance facing Africa at this point in time. It is of great importance that without godly men in politics and governance there may be no meaningful development. For instance, why is it that there is enormous corruption in Nigeria? It is there because of the kind of men that had been in political power since the country's independence. No wonder that corruption, ethnicity, fanaticism and selfishness have been institutionalized in African democratic system. One thing is certain, unless men with integrity and godly character like Wilberforce and his group go into governance; the change we may be clamouring for may end up being a mirage. Like the Clapham sect who took their wealth and time to fight the course of the oppressed, it is the responsibility of the God fearing men and women in our time to take it as a task to address our enormous social maladies.

In essence, present day evangelicals can use a healthy dose of Clapham Spirituality in other to bring about the long awaited transformation and development to Africa. At the same time, it is important to acknowledge that spiritual formation begins with conversion and it is often cultivated through personal and corporate spiritual disciplines. In this sense, spiritual formation includes faith-based activism that includes both the Great Commission to make disciples of all nations (Matt. 28:19-20) and the Great Commandment to love the Lord and love our neighbours (Matt. 22:36-40). Like the Clapham Sect, our spiritual transformation must inspire us to serve others through acts of mercy and clear gospel proclamation. Also, Christians need to use whatever public influence they might have for the sake of pursuing peace, unity and enduring values especially among the defenseless in our society. It is our responsibility to pour ourselves out in sharing the good news of Jesus Christ here, there and everywhere. 


\section{Conclusion}

It is arguable that Clapham Sect's commitment to personal spiritual formation contributed immensely to fuel the social activism of the $18^{\text {th }}$ and $19^{\text {th }}$ centuries. Their Spirituality was not only committed to what can be called matters of social justice today rather, it was also zealous for the propagation of the gospel to people of different race and status. Therefore, the contribution of this sect is so challenging in the sense that within a short time they made great impact in fostering evangelical Christianity, encouraged the Church Missionary Society and the British and Foreign Bible Society, and encouraged the good administration of India. Also, they encouraged education and backed the Sunday school movement, founded Freetown in Sierra Leone and stopped many ills in the society. In addition, they set higher standards of active concern in politics and pioneered the abolition of the slave trade. Hence, the ball of changing our world for the good of future generation rests on our shoulders. 


\section{References}

Ahlstrom, S.E (1972).A religious history of the American people. London: Yale University.

Bebbington, D. W (1993).Evangelicalism in modern Britain: A history from the 1730s to the 1980s, London: Rutledge.

Bradley, I.C (1974). The politics of godliness: Evangelicals in parliament, 1784 -1832. D Phil thesis: Oxford University.

Diane, S. (n.d).Evangelical revival in England. Retrieved on May $8^{\text {th }}, 2015$ from http://www.christianity.com/church/churchhistory/timeline/1701-1800/evangelical- revival-inengland-11630228.html.

Drucker, P. (1968).The practice of management.London: Pan books.

Finn, .N (n.d).Clapham spirituality: A model for contemporary evangelicals. Retrieved on May $8^{\text {th }}, 2015$ from http://www.canonandculture.com/clapham-spirituality-amodel-for-contemporary-evangelicals/

Hardman, O. (n.d). The Clapham sect. London: SPCK.

Hylson-Smith, K. (1988). Evangelicals in the Church of England,1734-1984.Edinburgh: T \& T Clark.

McKenzie, P. (2010). Public Christianity and TeTiriti o Waitangi: how the "Clapham Sect" reached down under. Stimulus, 18, 4, 23- 31 .

Newman, K. (2010). Bible and treaty. Auckland: Penguin.

Nnatuanya, C.E (2011). The seat of Crowther on the Niger: The journey so far. Onitsha: Sams.

Tomkins, S. (2010). The Clapham Sect: How Wilberforce's circle changed Britain. Oxford: Lion.

Richard G. (2001). William Wilberforce and his circle of friends.Retrieved on $8^{\text {th }}$ May, 2015 From http://www.cslewisinstitute.org/webfm_send/471. 